\title{
Diagnostic efficacy of molecular assays for the viral haemorrhagic septicaemia virus isolates from the Czech Republic
}

\author{
L'ubomír Pojezdal ${ }^{1,2}$, Dagmar Pokorová2 ${ }^{2}$ Stanislava Reschová2, Miroslava Palíková ${ }^{1}$, \\ Monika Vícenová ${ }^{2}$ Tomáš Veselý ${ }^{2}$, Stanislav Navrátil ${ }^{1}$ \\ ${ }^{1}$ University of Veterinary and Pharmaceutical Sciences Brno, Faculty of Veterinary Hygiene and Ecology, \\ Department of Ecology and Diseases of Game, Fish and Bees, Brno, Czech Republic \\ ${ }^{2}$ Veterinary Research Institute, Department of Virology, National Reference Laboratory \\ for Viral Diseases of Fish, Brno, Czech Republic
}

Received May 26, 2017

Accepted October 2, 2017

\begin{abstract}
The diagnostic properties of the one-step real-time reverse-transcription polymerase chain reaction assay for viral haemorrhagic septicaemia virus detection were compared to methods currently in use in the Czech Republic, namely, virus isolation using the cell culture and conventional reverse-transcription polymerase chain reaction followed by the nested polymerase chain reaction. The assays were tested on a panel of 25 archived viral haemorrhagic septicaemia isolates and 8 archived infectious haematopoietic necrosis isolates obtained from monitoring and/or outbreaks of the diseases among farmed salmonids in the Czech Republic. The ability to detect the presence of the virus in the tissues of fish was tested on additional 32 field samples collected from the rainbow trout (Oncorhynchus mykiss), brown trout (Salmo trutta) and brook trout (Salvelinus fontinalis). The real-time assay showed the highest analytic sensitivity by detecting the presence of viral nucleic acid in samples with $10^{-7}$ dilution, whereas the sensitivity of the conventional polymerase chain reaction peaked at $10^{-5}$. Diagnostic specificity of both molecular assays was confirmed by absence of cross-reactivity with the infectious haematopoietic necrosis virus isolates. This, along with consistent results in the detection of the virus in the fish tissues, confirms that the one-step real-time reverse-transcription polymerase chain reaction is currently an optimal stand-alone diagnostic method for the detection of the viral haemorrhagic septicaemia virus.
\end{abstract}

Cell culture, real-time PCR, RT-PCR, rainbow trout, Rhabdoviridae

Viral haemorrhagic septicaemia virus (VHSV) from the family Rhabdoviridae is the most important viral pathogen of salmonids worldwide. The enveloped single-stranded ribonucleic acid virus causes outbreaks of the viral haemorrhagic septicaemia (VHS) amongst over 80 fresh- and saltwater fish species and has an increasing economic impact due to clinical signs, high mortality from the disease and costly eradication measures (Skall et al. 2005). Intensive aquaculture production of rainbow trout (Oncorhynchus mykiss), which is the most economically relevant salmonid-related industry in the Czech Republic, is especially affected, with fish showing severe clinical signs such as haemorrhages in the muscle and organ tissue, exophthalmos, and ascites (Reichert et al. 2013). Neither reliable treatment nor vaccine against the VSHV is currently available. Control of the disease is based on prevention and surveillance programs (OIE Manual of Diagnostic Tests for Aquatic Animals 2016).

Diagnostic methods for detection of the virus with high sensitivity and specificity are the key components of these programs. The currently used methods meet these criteria, but their disadvantages are high time requirements (isolation on the cell culture) or higher risk of sample contamination (conventional reverse-transcription polymerase chain reaction [RT-PCR], enzyme-linked immunosorbent assay [ELISA]) (Mackay 2004).

Address for correspondence:

Lubomír Pojezdal

National Reference Laboratory for Viral Diseases of Fish

Veterinary Research Institute

Hudcova 296/70, 62100 Brno, Czech Republic 
A legislative option to use one-step real-time RT-PCR as a stand-alone method of VHSV diagnosis exists since 2016 (Commission Implementing Decision (EU) 2015/1554), although this method has not yet been validated for use in reference laboratory in the Czech Republic.

The aim of the present study was to test the real-time RT-PCR assay, as described by Jonstrup et al. (2013), on a panel of archived Czech VHSV isolates and field samples. Diagnostic sensitivity and specificity of the assay was compared to the diagnostic methods currently in use, namely isolation on the cell culture and conventional RT-PCR followed by nested PCR.

\section{Materials and Methods}

\section{Tissue samples}

In total, 169, 33, and 19 specimens of rainbow trout (Oncorhynchus mykiss), brown trout (Salmo trutta), and brook trout (Salvelinus fontinalis), respectively, were examined. The samples represented either fish farms with clinical outbreaks of the viral haemorrhagic septicaemia (VHS) or clinically healthy wild freshwater fish populations of the Southern Bohemian Region. The animals were collected from 2015 to 2017 and were pooled into 32 samples of up to 10 fish each, according to their species and place of origin.

The spleen, anterior kidney and heart of the fish were dissected, homogenized in the Minimum Essential Medium Eagle (MEM) HEPES modification (Sigma-Aldrich, USA) at the 1:10 tissue to medium ratio and centrifuged at $3000 \mathrm{~g}$ for $14 \mathrm{~min}$ at $4{ }^{\circ} \mathrm{C}$. The supernatant was used for further analysis.

\section{Virus isolates}

Twenty five additional isolates of the viral haemorrhagic septicaemia virus (VHSV) and 8 isolates of the infectious haematopoietic necrosis virus (IHNV) - a pathogen from the same family Rhabdoviridae - were obtained during the monitoring and/or outbreaks of the diseases in the Czech Republic during the period of 1996-2016. Presence of the VHSV or the IHNV in each archived sample was confirmed using cell culture isolation, conventional RT-PCR and nested PCR, according to Commission Decision (EU) 2001/183/EC.

\section{Cell cultivation}

The twenty five archived VHSV isolates used in this study were cultivated on the rainbow trout gonad (RTG-2) cell line in 24-well plates using the MEM HEPES modification with the addition of $10 \%$ foetal bovine serum, MEM non-essential amino acids, penicillin, streptomycin, and gentamicin used for cultivation. The plates were incubated at $15^{\circ} \mathrm{C}$ for 7 days. The wells were then observed under light microscope to assess the cytopathic effect (CPE) on the cell monolayer.

\section{Virus titration}

Monolayer of 24-hour-old RTG-2 cells was infected with series of dilutions of three selected virus isolates in a 24 well-plate. The resulting CPE was observed after one week of incubation. The titre of the virus was calculated using the Reed-Muench method (Reed and Muench 1938).

\section{Nucleic acid extraction}

Ribonucleic acid (RNA) was extracted either from cell culture supernatants, or from organ homogenate supernatants using the QIAamp Viral RNA Mini Kit (Qiagen, Germany) according to the manufacturer's instructions. The RNA extract was used for PCR or real-time PCR reactions either directly, or served as a matrix for tenfold serial dilutions sets.

\section{Primers}

Primers for RT-PCR and nested PCR were adopted from the protocols of the National Reference Laboratory for Viral Diseases of Fish in Brno, Czech Republic. The primers target the highly conservative part of the glycoprotein gene of the virus, whereas the primers and probe for the real-time RT-PCR published by Jonstrup et al. (2013) are targeted towards a part of the nucleoprotein gene (Table 1). All of the primers and probes were manufactured by Integrated DNA Technologies (USA).

\section{Polymerase chain reactions}

Reverse-transcription PCR was performed using the Titan One Tube RT-PCR System (Sigma Aldrich, USA). Each reaction contained both of the primers at the final concentration of $0.4 \mu \mathrm{M}$ each and $4 \mu 1$ RT-PCR reaction buffer $5 \times, 0.4 \mu \mathrm{l}$ RT-enzyme mix, $1.5 \mathrm{mM} \mathrm{MgCl}_{2}, 0.2 \mathrm{mM}$ deoxynucleotide mix (dNTP), $5 \mathrm{mM}$ dithiothreitol 
Table 1. Primers and probes for the polymerase chain reaction assays.

\begin{tabular}{ll}
\hline Primer name & Sequence \\
\hline RT-PCR FW & 5' - ATG GAA TGG AAC ACT TTT TTC - 3' \\
RT-PCR BW & 5' - AAC CCC CTC TAT GAA ATC - 3' \\
Nested PCR FW & 5' - TCA TCA TAA AGA GCA CCA CAC C - 3' \\
Nested PCR BW & 5'- ATG GTT TGC CCT CCA AAG AAG C - 3' \\
Real-time RT-PCR FW & 5' - AAA CTC GCA GGA TGT GTG CGT CC - 3' \\
Real-time RT-PCR BW & 5' - TCT GCG ATC TCA GTC AGG ATG AA - 3' \\
Real-time RT-PCR Probe & 5'- 6-FAM TAG AGG GCC TTG GTG ATC TTC TG BHQ-1 - 3' \\
\hline
\end{tabular}

RT-PCR: conventional reverse-transcription polymerase chain reaction, Nested PCR: nested polymerase chain reaction, Real-time RT-PCR: real-time reverse-transcription polymerase chain reaction, FW: sense oriented primer, BW: anti-sense oriented primer

(DTT), 40 enzyme units (U) of Recombinant RNasin Ribonuclease Inhibitor (Promega, USA) and $2.4 \mu 1$ of the RNA extract for the total volume of $20 \mu \mathrm{l}$. The reaction was performed using the TC-XP Cycler (Bioer Technologies, China) with $30 \mathrm{~min}$ at $50{ }^{\circ} \mathrm{C}, 2.5 \mathrm{~min}$ at $94{ }^{\circ} \mathrm{C}$, followed by 34 cycles of $30 \mathrm{~s}$ at $94{ }^{\circ} \mathrm{C}, 1 \mathrm{~min}$ at $50{ }^{\circ} \mathrm{C}$ and $1 \mathrm{~min}$ at $68^{\circ} \mathrm{C}$. The cycles were followed by $7 \mathrm{~min}$ at $68^{\circ} \mathrm{C}$.

Nested PCR was based on GoTaq ${ }^{\circledR}$ G2 Flexi DNA Polymerase kit (Promega, USA). One $20 \mu 1$ reaction contained both of the respective primers at the final concentration of $0.1 \mu \mathrm{M}$ each and consisted of $4 \mu 15 \times$ FlexiPCR buffer, $2.5 \mathrm{mM} \mathrm{MgCl}_{2}, 0.25 \mathrm{mM} \mathrm{dNTP}, 1.25 \mathrm{U}$ GoTaq DNA polymerase, and $0.2 \mu 1$ of the PCR product from the described RT-PCR. The reaction was performed using the TC-XP Cycler (Bioer Technologies, China), starting with 24 cycles of $30 \mathrm{~s}$ at $94{ }^{\circ} \mathrm{C}, 30 \mathrm{~s}$ at $60{ }^{\circ} \mathrm{C}$ and $30 \mathrm{~s}$ at $72{ }^{\circ} \mathrm{C}$. The cycles were followed by $30 \mathrm{~s}$ at $94{ }^{\circ} \mathrm{C}$, $30 \mathrm{~s}$ at $60^{\circ} \mathrm{C}$ and $7 \mathrm{~min}$ at $72^{\circ} \mathrm{C}$.

Real-time RT-PCR was performed in duplicates, using the setting described by Jonstrup et al. (2013). Each $25 \mu \mathrm{l}$ reaction based on the QuantiTect Probe RT-PCR kit (Qiagen, Germany) contained the probe at the final concentration of $0.25 \mu \mathrm{M}$ and both of the primers at the concentration of $0.9 \mu \mathrm{M}$ each, along with $5 \mu 1$ RNA extract, $0.25 \mu 1$ QuantiTect RT Mix and $12.5 \mu 12 \times$ QuantiTect Probe PCR Master Mix. The reaction was performed using LightCycler 480 System (Roche, Switzerland) with $30 \mathrm{~min}$ at $50{ }^{\circ} \mathrm{C}$ and $15 \mathrm{~min}$ at $95{ }^{\circ} \mathrm{C}$ followed by 40 cycles of $15 \mathrm{~s}$ at $94{ }^{\circ} \mathrm{C}, 40 \mathrm{~s}$ at $60^{\circ} \mathrm{C}$ (with endpoint data collection) and $20 \mathrm{~s}$ at $72{ }^{\circ} \mathrm{C}$.

\section{Results}

Comparison of detection methods

After one-week cultivation on the RTG-2 cell line, visible CPE was observed in 18 out of 25 wells infected with separate archive isolates of the virus. Reverse-transcription PCR followed by nested PCR, detected the presence of the virus in 24 out of 25 of the originally provided virus isolates. The real-time RT-PCR was able to identify the RNA of VHSV in all of the original samples, with threshold cycle $\left(\mathrm{C}_{\mathrm{t}}\right)$ values ranging from 17.33 to 33.64 (Table 2). The Spearman's correlation coefficient between $\mathrm{CPE}$ and $\mathrm{C}_{\mathrm{t}}$ values was calculated at 0.65 (Spearman 1906).

\section{Sensitivity and specificity}

Analysis of the tenfold serial dilutions of RNA extracts of the virus using conventional RT-PCR showed the presence of the viral RNA in a $10^{-5}$ dilution. The same RNA extract dilutions were analysed by real-time RT-PCR, where the assay was able to detect the RNA of the virus in a dilution of $10^{-7}$, with the mean $\mathrm{C}_{t}$ value of 32.2. The amplification efficiency of these reactions was calculated as $106 \%$. The $\mathrm{C}_{t}$ values between duplicates or repeated experiments remained within the limit of $0.8 \mathrm{C}_{\mathrm{t}}$. Neither conventional RT-PCR nor real-time RT-PCR did cross-react with the IHNV virus present in the eight IHNV positive samples tested. 
Table 2. Results of the cell culture isolation and the real-time reverse-transcription polymerase chain reaction of the 25 archived viral haemorrhagic septicaemia virus isolates.

\begin{tabular}{|c|c|c|c|c|c|}
\hline VHSV Isolate & Year & Region of origin & Species of origin & CPE & $\mathrm{C}_{\mathrm{t}} *$ \\
\hline CZ-96 0000 & 1996 & Plzen̆ & Oncorhynchus mykiss & + & 25.90 \\
\hline CZ-99_0504 & 1999 & Southern Bohemian & Oncorhynchus mykiss & - & 28.02 \\
\hline CZ-00_0560 & 2000 & Southern Bohemian & Oncorhynchus mykiss & + & 25.81 \\
\hline CZ-00_0574 & 2000 & Southern Bohemian & Oncorhynchus mykiss & + & 26.79 \\
\hline CZ-00_0582 & 2000 & Moravian-Silesian & Oncorhynchus mykiss & ++ & 17.30 \\
\hline CZ-01_0661 & 2001 & Plzeň & Oncorhynchus mykiss & +++ & 18.64 \\
\hline CZ-03_0797 & 2003 & Plzeň & Oncorhynchus mykiss & - & 25.42 \\
\hline CZ-04_0927 & 2004 & Southern Bohemian & Oncorhynchus mykiss & - & 22.67 \\
\hline CZ-07_1292 & 2007 & Pardubice & Oncorhynchus mykiss & - & 30.26 \\
\hline CZ-08_1328 & 2008 & Olomouc & Oncorhynchus mykiss & - & 23.95 \\
\hline CZ-08_1391 & 2008 & Southern Bohemian & Oncorhynchus mykiss & + & 29.05 \\
\hline CZ-08_1397 & 2008 & South Moravian & Oncorhynchus mykiss & - & 23.65 \\
\hline CZ-10 1662 & 2010 & Vysočina & Oncorhynchus mykiss & ++ & 19.19 \\
\hline CZ-10_1674 & 2010 & Southern Bohemian & Oncorhynchus mykiss & - & 33.64 \\
\hline CZ-11_1748/2 & 2011 & Plzeň & Salvelinus fontinalis & +++ & 22.52 \\
\hline CZ-11_1748/3 & 2011 & Southern Bohemian & Oncorhynchus mykiss & + & 18.18 \\
\hline CZ-13_1838 & 2013 & Southern Bohemian & Oncorhynchus mykiss & ++ & 22.90 \\
\hline CZ-13_1842 & 2013 & Olomouc & Oncorhynchus mykiss & +++ & 22.80 \\
\hline CZ-13_1844 & 2013 & Moravian-Silesian & Oncorhynchus mykiss & +++ & 19.44 \\
\hline CZ-13_1848 & 2013 & Moravian-Silesian & Oncorhynchus mykiss & ++ & 23.66 \\
\hline CZ-13_1856 & 2013 & Southern Bohemian & Oncorhynchus mykiss & +++ & 21.91 \\
\hline CZ-14_1896 & 2014 & Vysočina & Oncorhynchus mykiss & +++ & 21.92 \\
\hline CZ-14_1904 & 2014 & Vysočina & Oncorhynchus mykiss & +++ & 19.42 \\
\hline CZ-14 1917 & 2014 & Moravian-Silesian & Oncorhynchus mykiss & + & 23.47 \\
\hline CZ-15 1939 & 2015 & Karlovy Vary & Oncorhynchus mykiss & +++ & 22.81 \\
\hline
\end{tabular}

$\mathrm{CPE}=$ cytopathic effect on the RTG-2 cell-line after 7-day-long cultivation

$\mathrm{C}_{\mathrm{t}}=$ threshold cycle of the real-time RT-PCR *Values are mean \pm standard deviation of duplicate runs

\section{Virus titres}

Fifty percent tissue culture infective dose per millilitre $\left(\mathrm{TCID}_{50} / \mathrm{ml}\right)$ of three of the isolates was determined as follows: CZ-14_1904: 10 2.4 , CZ-14_1896: $10^{1.3}$ and CZ-14_1917: 10.5. The mean $\mathrm{C}_{\mathrm{t}}$ values of these isolates, as detected on RTG-2 cell culture, were 19.42, 21.92 and 23.47 , respectively.

\section{Animal tissue examination}

Viral RNA was detected in 8 of 32 samples examined for the presence of VHSV using real-time RT-PCR. All of the positive samples were collected on fish-farms with clinical outbreaks of VHS. The virus was not detected in samples containing wild fish, brook trout or brown trout tissues. The results of real-time RT-PCR were confirmed using cell cultivation followed by virus identification using conventional RT-PCR and nested PCR, according to Commission Decision (EU) 2015/1554 (Table 3).

\section{Discussion}

A potential method of virus identification must have high analytical and diagnostic sensitivity in order to minimize false-negative results. The current gold standard for the 
Table 3. Results of animal tissue examination.

\begin{tabular}{lrcrc}
\hline Species & Fish & Samples (pooled) & \multicolumn{2}{c}{$\begin{array}{c}\text { VHSV positive samples } \\
\text { Conventional** }\end{array}$} \\
\hline Oncorhynchus mykiss & 169 & 24 & $8 / 24$ & $8 / 24$ \\
Salmo trutta & 33 & 4 & $0 / 4$ & $0 / 4$ \\
Salvelinus fontinalis & 19 & 4 & $0 / 4$ & $0 / 4$ \\
\hline Total & 221 & 32 & $8 / 32$ & $8 / 32$ \\
\hline
\end{tabular}

*Real-time: real-time reverse-transcription polymerase chain reaction **Conventional: cell cultivation followed by conventional RT-PCR and nested PCR

isolation of rhabdoviruses from salmonids is the cell culture isolation (Lorenzen et al. 1999). This method is highly sensitive, but has some major disadvantages. It is timeconsuming, with 7-10 days of the cultivation period and subsequent subcultivation of the same length. The stand-alone cell culture isolation cannot distinguish between various viral species, it must therefore always be followed by an additional virus identification method, such as ELISA or RT-PCR (OIE Manual of Diagnostic Tests for Aquatic Animals 2016). Both of these methods require multiple steps with repeated opening of the tubes with the reaction mix or product, which increases the risk of sample contamination, along with the risk of a human error resulting in possible false results (Mackay 2004).

One-step RT-PCR has proven to have higher analytical sensitivity than conventional methods by detecting the presence of viral nucleic acids in samples with a higher degree of dilution. Real-time RT-PCR was also the only method able to detect the presence of VHSV in the isolate CZ-10_1674. The extremely high $\mathrm{C}_{t}$ value of this sample is suspected to be a consequence of decay of the virus during the storage period and it shows that in contrast to cell culture-based methods, the assay is able to diagnose the presence of the viral RNA even in cases when there are no viral particles able of infection left (Jonstrup et al. 2013).

The $\mathrm{C}_{t}$ values of samples examined varied, with the main reason being the different virus quantities in individual samples, as shown by the determination of titres of three selected virus isolates. The correlation between virus titre and the resulting $\mathrm{C}_{\mathrm{t}}$ value of the aforementioned samples, along with the high Spearman's correlation coefficient between $\mathrm{C}_{t}$ values and observed CPE status of the cell cultures infected with 25 archived VHSV isolates shows the semi-quantitative nature of the real-time RT-PCR assay. The potential of real-time PCR to serve as a method of enumeration of the amount of the viral particles (or copies of its nucleic acid) in separate tissues was already described for other viruses of fish (Gilad et al. 2004).

Another reason for the differences in $\mathrm{C}_{\mathrm{t}}$ values amongst individual isolates of the virus might be in the genetic variability of the examined material (Pierce and Stepien 2012). Although the tested real-time RT-PCR assay was proven to be sensitive to all of the defined VHSV genotypes (Jonstrup et al. 2013), there are currently no available data on the genetic properties of the VHSV isolates from the Czech Republic. A future study on this topic is warranted.

Neither real-time nor conventional RT-PCR did cross-react with any of the samples containing infectious haematopoietic necrosis virus, another viral pathogen of farmed salmonids belonging to the family Rhabdoviridae. The absence of cross-reaction shows the reliability of diagnostic specificity of both molecular methods (Snow et al. 2004).

The cell-culture isolation alone is not designed to distinguish between various species of viral pathogens and was not tested as such. Its ability to isolate a wide variety of viruses should be considered advantageous for a situation, in which a strain of VHSV mutates 
outside of the detection range of the currently used molecular assays (Einer-Jensen et al. 2004). Another advantage of the cell culture-based methods compared to the molecular assays, is the ability to obtain an infectious isolate of the virus.

The potential of real-time RT-PCR to serve as a stand-alone routine diagnostic tool for VHSV detection in fish tissues was confirmed using field samples. The analysis of the internal organ homogenates from 221 fish specimens proved that the assay is capable of identifying VHSV positive animals and distinguishing them from negative samples at least to the same degree, as the conventionally used cell culture isolation followed by conventional RT-PCR and nested PCR (Garver et al. 2011). The use of real-time PCR significantly shortens the time period needed for routine examination of the animal tissue for the presence of the virus.

\section{Acknowledgements}

This study was supported by the project IGA VFU Brno No. 238/2015/FVHE and the Project MZE-RO0517 of the Ministry of Agriculture of the Czech Republic.

\section{References}

Commission Decision (EU) 2001/183/EC of 22 February 2001 laying down the sampling plans and diagnostic methods for the detection and confirmation of certain fish diseases and repealing Decision 92/532/EEC

Commission Implementing Decision (EU) 2015/1554 of 11 September 2015 laying down rules for the application of Directive 2006/88/EC as regards requirements for surveillance and diagnostic methods

Einer-Jensen K, Ahrens P, Forsberg R, Lorenzen N 2004: Evolution of the fish rhabdovirus viral haemorrhagic septicaemia virus. J Gen Virol 85: 1167-1179

Garver KA, Hawley LM, McClure CA, Schroeder T, Aldous S, Doing F, Snow M, Edes S, Baynes C, Richard J 2011: Development and validation of a reverse transcription quantitative PCR for universal detection of viral hemorrhagic septicemia virus. Dis Aquat Org 95: 97-112

Gilad O, Yun S, Zagmutt-Vergara FJ, Leutenegger CM, Bercovier H, Hedrick RP 2004: Concentrations of a Koi herpesvirus (KHV) in tissues of experimentally infected Cyprinus carpio koi as assessed by real-time TaqMan PCR. Dis Aquat Organ 60: 179-187

Jonstrup SP, Kahns S, Skall HF, Boutrup TS, Olesen NJ 2013: Development and validation of a novel Taqmanbased real-time RT-PCR assay suitable for demonstrating freedom from viral haemorrhagic septicaemia virus. J Fish Dis 36: 9-23

Lorenzen E, Carstensen B, Olesen NJ 1999: Inter-laboratory comparison of cell lines for susceptibility to three viruses: VHSV, IHNV and IPNV. Dis Aquat Org 37: 81-88

Mackay IM 2004: Real-time PCR in the microbiology laboratory. Clin Microbiol Infect 10: 190-212

OIE Manual of Diagnostic Tests for Aquatic Animals 2016. Available at:

http://www.oie.int/international-standard-setting/aquatic-manual/access-online/

Pierce LR, Stepien CA 2012: Evolution and biogeography of an emerging quasispecies: Diversity patterns of the fish Viral Hemorrhagic Septicemia virus (VHSv). Mol Phylogenet Evol 63: 327-341

Reed LJ, Muench H 1938: A simple method of estimating fifty percent endpoints. Am J Epidemiol 27: 493-97

Reichert M, Matras M, Skall HF, Olesen NJ, Kahns S 2013: Trade practices are main factors involved in the transmission of viral haemorrhagic septicaemia. J Fish Dis 36: 103-114

Skall HF, Olesen NJ, Mellergaard S 2005: Viral haemorrhagic septicaemia virus in marine fish and its implications for fish farming - a review. J Fish Dis 28: 509-529

Snow M, Bain N, Black J, Taupin V, Cunningham CO, King JA. Skall HF, Raynard RS 2004: Genetic population structure of marine viral haemorrhagic septicaemia virus (VHSV). Dis Aquat Org 61: 11-21

Spearman C 1906: The Proof and Measurement of Association between Two Things. Am J Psychol 15: 72-101 